\title{
CHANGING RULES OF LIABILITY IN AUTOMOBILE ACCIDENT LITIGATION
}

\author{
RICHARD M. NIXON*
}

Thirty-one years ago an enterprising law review commentator discussed in a four-page article all the reported cases dealing with the tort liability of automobile drivers. ${ }^{1}$ He predicted that the great number of motor cars, "constantly whizzing through villages, towns, cities, counties, and across the states are bound to call forth from the courts judicial utterances peculiar to the automobile's status."2 The courts before and since that time, almost without exception, have insisted that the rules of law applicable to automobile cases, were no different from those which had been developed in the days of the horse and buggy. But there has, nevertheless, grown up a large body of law which shows clearly the influence of the automobile and much of which is applicable only to automobile cases. Thus, though the advocates of legal reform are directing a steadily increasing stream of criticism at the rules which govern liability in automobile litigation, at least they cannot damn them all with that machine-age epithet, "horse and buggy."

So numerous have these changes been that comprehensive, detailed treatment would call for an encyclopedia, not an article. But so far as generalization can be hazarded, it may be said that there has been a steady erosion of fault as the ground of shifting the plaintiff's loss to the defendant. This article will be directed to an examination of three significant fields of automobile accident law in which the working of this process is apparent and then deal with a fourth field in which precisely the opposite trend is evident. ${ }^{3}$

\section{The Standard of Care}

Despite the insistent contention of counsel in the early cases $^{4}$ that the absolute liability of the keeper of vicious dogs or evilly-disposed mules should be imposed upon the drivers of "devil wagons," the courts from the beginning held that the

- A.B., 1934, Whittier College. Now a member of the third year class, Duke University School of Law. President, Duke Bar Association. Member of the Editorial Board of the Duke Bar Association Journal.

${ }^{1}$ Huddy, The Law of Automobiles (r905) 9 LAw Notes (Am.) 147.

${ }^{2}$ Ibid.

${ }^{3}$ Because of limited space, no attempt will be made to give exhaustive citations.

'See Blakemore, Is the Law Fair to the Motor Vehicle? (193I) 65 U. S. L. Rev. 20, 21.

${ }^{5}$ So the automobile was once labelled. See Note (1906) I L. R. A. (N. S.) 215, 225; (1904) 59 Cenr. L. J. 432 . 
automobile driver should be subject to liability only if his conduct were at fault and then only to plaintiffs whose conduct was free from fault. "Fault" was defined in terms of a departure from the common law standard of ordinary care. The courts thereby took upon themselves the problem of determining in each case whether the parties had exercised the required degree of care. In the days of poor roads and low speeds, the facts of an accident could be reconstructed in the courtroom with some degree of accuracy, and the problem of determining fault did not present unusual difficulties. But with high-powered cars and concrete highways, the probability that an accident-often the consequence of a fractional mistake in management-can and will be described accurately in court has become increasingly remote, especially where court congestion has delayed the time of trial. The consequent uncertainties as to the facts have given to the jury in those cases where it determines the question of fault an almost unrestricted power to choose between the litigants at bar. And the notorious tendency of that body to prefer the plaintiff, ${ }^{7}$ especially as against the defendant suspected of carrying insurance, has made "taking the case away from the jury" one of the primary objectives of the defense counsel.

To this end they have invoked the power of the trial judge to direct a verdict for the defendant if the evidence clearly demonstrates either the plaintiff's fault or the defendant's freedom from fault. But so long as the standard of care is that which a reasonable man would have exercised under the circumstances, the opportunity for such a demonstration is obviously limited. Where, however, the standard of care governing a specific situation has become crystallized in a rule of law, e.g. that a driver approaching a railroad crossing must "stop, look, and listen," the power of the trial judge is materially increased for the evidence may clearly show whether that standard was observed by the party to whom it is applicable.

It is not surprising then that it has been around the standard of care that some of the most important battles of automobile tort law have been waged. And the conflict has been most acute with respect to the standard of care applicable to the plaintiff. A specific standard of care is, as a rule, a more rigorous requirement than the general standard of the "reasonable man." For plaintiff's counsel, already enjoying the favor of the jury, the need to obtain a directed verdict based upon a proved deviation from a specific standard is less important than for defendant's counsel who will strive to wrest the case from the jury by seeking a directed verdict based on the plaintiff's failure to observe such a standard. It is in the rise and decline of those specific standards of care most frequently invoked against plaintiffs that change in the rules of liability in automobile cases can best be marked. ${ }^{8}$

\footnotetext{
'Lewis v. Amorous, 3 Ga. App. 50, 59 S. E. 338 (1907), is a typical decision refusing to impose absolute liability on the automobile owner.

7 Thus in a survey covering courts of four cities it was found that verdicts for plaintiffs were rendered in approximately two-thirds of the cases. See Report by the Committee to Study Compensation for Automonile Accidents (1932) 34.

${ }^{8}$ An example of a standard of care invoked against defendants is found in the development of the rules applicable to the horse-frightening cases. In the early cases, the common law standard of ordinary care was laid down. But as the number of cases of this type increased, the courts began to lay down exact
} 
The specific standard of care in civil cases is usually either of judicial creation or adoption. When a judge has discovered through hearing a number of cases involving similar situations that certain conduct is generally blameworthy he may rule that a person guilty of such conduct is negligent as a matter of law.' If the appellate court approves his ruling, or if that court itself so rules, the standard becomes a rule of law to be followed in all future cases involving similar facts. A similar power resides in the legislature, but it has acted principally through the creation of standards of care by which the criminal liability of an individual is to be measured. However, in a majority of the states, the courts in civil cases involving legislatively proscribed conduct have ruled that such conduct is negligence as a matter of law..$^{10}$ In other states, however, the courts have considered that the violation of the criminal statute is no more than evidence of negligence which the jury may weigh, along with the other facts of the case, in deciding the fault question. ${ }^{11}$

An inquiry into the history of three specific standards which have played an important part in automobile litigation follows.

I. The Stop, Look, and Listen Rule.

Before the coming of the automobile, many cases had come before the courts in which the point at issue was whether or not a traveller had exercised due care in crossing a railroad track. At first the courts left the standard of care to be defined by the jury, but gradually judicial standards began to emerge. In the language of the Supreme Court of California, "The cases arising from injuries suffered at railroad crossings have been so numerous, and upon certain points, there has been such absolute accord, that what will constitute ordinary care in such a case will have been precisely defined, and if any element is wanting, the courts will hold as a matter of law that the plaintiff has been guilty of negligence."12 It was not until the automobile became a factor in the cases that the greatest development of judicial standards took place..$^{13}$ Courts which had required the driver of the horse and buggy only to look and listen, adopted as the standard for the automobile operator, the strict Pennsylvania rule of stopping. ${ }^{14}$ But as the number of crossing cases increased, the courts began to make exceptions to the rules they had laid down, and some ceased to apply absolute standards, holding that each case must stand on its own facts and that the question of due care should be one for the jury. ${ }^{15}$

rules for particular situations. Thus it was held to be negligent per se for the automobile driver not to stop if the driver of the horse signalled him or if the horse appeared frightened. The legislature passed stantes which were applied in civil cases. Finally a fairly exact set of rules governed the conduct of the automobile driver in this type of situation, and the driver of the horse had little difficulty in making out his case. See in general Berry, Rights and Duties of Automobile Drivers when Meeting and Passing Horse-Drawn Vehicles (rgr6) 82 CENT. L. J. 315.

- See Holmes, The Common Law (188' I) 122 et seq.

${ }^{10}$ Morris, The Relation of Criminal Statutes to Tort Liability (1933) 46 HArv. L. REv. 453.

21 Ibid.

2 See Herbert v. Southern Pac. Co., 121 Cal. 227, 230, 53 Pac. 651 (1898).

${ }^{13}$ See Note (1923) 9 VA. L. Rev. $3 x 7 . \quad{ }^{26}$ See Note (1928) I6 Cal. L. Rev. 238, 239.

${ }^{25}$ For examples of cases showing the relaxation of the rule and the exceptions made thereto, see Notes (I919) I A. L. R. 208; (1926) 4 I A. L. R. 420. 
In 1927 , in the case of Baltimore and Ohio R. R. v. Goodman, ${ }^{10}$ the Supreme Court, speaking through Mr. Justice Holmes, advocated strongly the fixing of definite standards in such cases. The standard there laid down in a dictum was that where the plaintiff could not otherwise ascertain whether or not a train was dangerously near, he should get out of his car. ${ }^{17}$ Although the case evoked a great deal of comment at the time, the trend away from the fixed standards was not noticeably checked.18 In 1934, Justice Cardozo, in Pokora v. Wabash Ry., ${ }^{18}$ refused to apply the standard laid down in the Goodman case. The Court did not, however, as is sometimes contended, advocate the abandonment of all fixed standards in such cases; its only quarrel was with the standard which had been laid down. It advised the use of "caution in framing standards of behavior that amount to rules of law-when there is no background of experience out of which the standards have emerged."20

Nevertheless the tendency today is definitely away from the application of fixed judicial standards in these cases. That statutes in many states impose criminal liability for failure to stop at a crossing, has had little effect due to the fact that a great proportion of them expressly stipulate that the rule of civil liability shall not be affected. ${ }^{21}$

\section{The Range of Vision Rule}

So prevalent once were accidents involving the collision of automobiles with unlighted horse-drawn vehicles at night, that the Supreme Court of one state held constitutional a county ordinance entirely prohibiting motor vehicles from travelling on the highway between dusk and dawn. ${ }^{22}$ It is not then surprising that as early as Ig09 a court laid down a judicial standard to govern a fact situation which was often involved in these cases. Where an automobile collided with an unlighted object at night, the driver's conduct was held to bo sub-standard as a matter of law unless he was travelling at such a speed that he could have stopped within the range of his headlights. ${ }^{23}$ This rule until recently was that of a majority of the courts, ${ }^{24}$ and for a time it was applied without material qualification. But as cases came before the courts wherein an arbitrary application of the rule seemed unjust, the courts began to make exceptions. Typical of these were the cases where adverse weather hindered visibility ${ }^{25}$ or where the unexpectedness of the obstruction contributed to the driver's failure to see it. ${ }^{26}$

Some courts completely abandoned the fixed standard holding that the question

${ }^{10} 275$ U. S. 66 (1927).

${ }^{17}$ Id. at 70 .

10292 U. S. 98 (1934).

${ }^{18} \dot{S}$ Se Note (1930) 43 Harv. L. Rev. 926, 929.

${ }^{20}$ Id. at 105 .

nThe statutes are collected in Note (I930) 43 Harv. L. Rev. 926, 93 I.

"Ex parte Berry, 147 Cal. 523, 82 Pac. 44 (1905).

- Lauson v. Town of Fond du Lac, I4I Wis. 57, 123 N. W. 629 (1909).

${ }^{24}$ See (1932) 4 RockY Mr. L. REv. 156, 158.

${ }^{20}$ Woolner v. Perry, 265 Mass. 74, I63 N. E. 750 (1928); Mechler v. McMahon, $x 84$ Minn. 476, 239 N. W. 605 (193I).

Opple v. Ray, 195 N. E. 81 (Ind. 1935); Jacobs v. Monize, 192 N. E. 515 (Mass. 1934). 
of fault in each case must be decided by the jury. ${ }^{27}$ In recent years statutes have been passed in several states providing that a motorist shall not drive at such a speed that he will be unable to stop within the assured clear distance ahead.28 The courts have declared that these statutes indicate a legislative intention that the range of vision rule be adopted as a standard in civil cases. ${ }^{20}$ If such legislation continues to find favor in the states, the range of vision rule may regain its former status.

\section{Statutory Right of Way at Intersections}

In view of the number of intersection collision cases which have come before the courts, it would be expected that some fairly definite judicial standards of conduct would have been developed. The courts did lay down the rule that the person reaching the intersection first should be entitled to the right of way. ${ }^{30}$ The standards applied in these cases have for the most part, however, been set by the legislatures. In many jurisdictions statutes provide that the person approaching the intersection from the right shall be entitled to the right of way. ${ }^{31}$ These statutes would seem to have established an arbitrary rule of law which would decide the right of litigants in all intersection cases. But though this exact standard was laid down in some of the early cases in which the statute was invoked, ${ }^{32}$ the courts have placed so many qualifications on the rule, that in most cases, it operates only as one element to be considered by the jury along with the other facts in determining the standard of care. Thus it is held that the party having the right of way may not exercise it without due regard for the rights of the other party, since the care to avoid collisions remains reciprocal. ${ }^{33}$ Whether the former can rely on the latter's giving him the right of way, is a jury question dependent on such circumstances as the width of the street, the number of vehicles crossing the intersection, the scope of the other's view, and the facility with which each car can be halted or controlled. ${ }^{34}$ The rule does not apply where the driver from the left had no knowledge of an obscured crossing. ${ }^{35}$ He may assume that the favored party is travelling at the lawful rate of speed. ${ }^{36}$ He need surrender the right of way only when all the circumstances, including the visible conduct of the favored party, combine to create a situation which would cause a reasonably

${ }^{27}$ For collection of cases see Comment (1935) 23 CAL. L. Rev. 498, 501. Compare Notes (1926) 44 A. L. R. 1403; (1929) 58 A. L. R. 1493; (1933) 87 A. L. R. 900; (1935) 97 A. L. R. 546, illustrating the growth of exceptions to the rule.

${ }^{23}$ Comment (1935) 23 Cal. L. Rev. 498, 502.

${ }^{20}$ Peckinpaugh v. Engelke, 215 Ia. 1248, 247 N. W. 822 (1933); Skinner v. Penn. R. R., 127 Ohio St. 69,186 N. E. 722 (1933).

${ }^{30}$ Note (I925) 37 A. L. R. 493,494 .

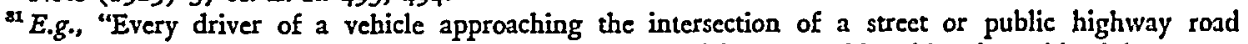
shall grant the right of way at such intersection to any vehicle approaching him from his right, except where otherwise directed by a traffic officer or a lawful regulation device or signal." $N$. Y. Cons. Laws (Cahill, x930) c: $64-a, \S \S 82,90$.

${ }^{3}$ Brillinger v. Ozias, 186 App. Div. 221, 174 N. Y. Supp. 282 (1919), is a particularly strong case. See also Note (1922) 21 A. L. R. 974.

Fitts v. Marquis, 127 Me. 75, 140 Atl. 909 (1928).

3 Ray v. Brannan, 196 Ala. 113, 72 So. 16 (1916). .

${ }^{2}$ Ramp v. Osborne, II5 Ore. 673, 239 Pac. Ir2 (1925).

* McHugh v. Mason, 154 Wash. 572, 283 Pac. I84 (r929). 
prudent man acting in relation thereto, to apprehend danger in not stopping. ${ }^{37}$ It is not surprising that a New York court, in commenting on the confusion which existed regarding the rights of parties at intersections, declared that the statute giving the right of way to the party approaching from the right was one of the principle causes thereof. 38

Of the standards heretofore discussed, the first two are applicable almost entirely to the conduct of plaintiffs, and the majority of those cases in which exceptions to the third have been made were ones in which the rule had been invoked against the plaintiff. ${ }^{39}$ Through the gradual demolition of these standards, the jury in an increasing number of cases has gained the power of determining whether the plaintiff had been at fault. The jury, however, may not be entirely without scruple in deciding this question. For according to Judge Ulman of the Baltimore Supreme Court, where the jury finds that both parties were at fault, it may ignore the coure's instruction to deny recovery to the plaintiff, but it will reduce the damages in proportion to his fault. ${ }^{40}$

\section{Judicial and Legislative Inroads upon the Freedom from Fault Requirement}

The courts have not confined their attack on the rule that the plaintiff must be free from fault to the subtle method, discussed in the preceding section, of depriving the trial judge of specific standards by which he might rescue the defendant from the fault judgment of a hostile jury. In using that method, they at least have proceeded on the assumption that if the jury finds the plaintiff's conduct to have been sub-standard, he should be barred from recovery. But the opponents of the doctrine have devised ways of avoiding its harsh effects even where the plaintiff is found guilty of fault. This section will be devoted to a discussion of those exceptions to the rule which have proved especially applicable to automobile accident litigation.

\section{Judicial Exceptions to the Doctrine of Contributory Negligence}

By the art of definition, the courts had determined before the advent of the automobile that the plaintiff's contributory negligence will not bar him from recovery where the defendant's conduct can be classed as wanton, willful or reckless. ${ }^{41}$ This result is reached by holding that contributory negligence should be a defense only to liability based on negligence. ${ }^{42}$ Then, although the courts will not distinguish

\footnotetext{
${ }^{7}$ See Note (193I) 3 Rocky Mr. L. Rev. 143, 147. For other typical exceptions showing that the rule today is only a relative one to be considered with all other factors, sec Note (1934) 89 A. L. R. $83^{8}$ and sources there cited.

${ }^{39}$ Shuman v. Hall, 246 N. Y. 5I, 54, I58 N. E. I6, I7 (r927).

${ }^{30}$ E.g., compare the number of cases in which the plaintiff's breach of the right of way statute was at issue with those involving defendants in cases abstracted in Notes (1922) 21 A. L. R. 974; (1925) 37 A. L. R. 493; (1927) 47 A. L. R. 595; (1929) 58 A. L. R. I197; (1932) 81 A. L. R. 185; (1934) 89 A. L. R. 839 .

${ }^{20}$ Ulman, A Judge Takes the Stand (1933) $3 \mathrm{x}-34$.

"Note (1932) 32 Col. L. Rev. 493, 500.

"See Lowndes, Contributory Negligence (1934) 22 Geo. L. J. 674, 686, for other exceptions to the rule based on this premise.
} 
between degrees of negligence, they find that willful, wanton, or reckless conduct is different from ordinary negligence not only in degree but also in kind. ${ }^{43}$ It is said that willfulness has an element of intentional wrongdoing; that it is the conscious, as contrasted to the inadvertent, doing of a negligent act.44 But in applying this test to the conduct of an automobile driver, little more can be done than to allow the jury to determine whether the defendant was conscious of his wrongdoing whenever it appears, objectively, that he has been very negligent.

That conventional liability safety valve, the causation analysis, forms the basis for the most fertile judicial exception to the doctrine of contributory negligence. Where the plaintiff by an act of negligence places himself in a position of peril, one who has a "last clear chance" to avoid injuring him and fails to exercise it, is held liable on the ground that his negligence, not the plaintiff's, was the proximate cause of the injury, although such a holding normally involves an arrant manipulation of the rules of causation. Explained also in terms of cause and condition, decisive cause and inducing cause, active and passive negligence, ${ }^{45}$ the doctrine of the last clear chance, has cut deeply into the rule which bars from recovery a plaintiff guilty of fault. For though a literal interpretation of the doctrine would require knowledge of the plaintiff's peril by the defendant, giving him an actual last clear chance to avoid the accident, the greater number of states apply it if the defendant, by the exercise of care, should have seen and recognized the danger. ${ }^{40}$ And although the rationale of the doctrine assumes that the plaintiff's negligence ceased to operate, some courts allow recovery even where the plaintiff, by the exercise of care, could have extricated himself from peril.47 Since its application turns on the solution of a complicated fact problem, the plaintiff's counsel who is able to invoke the doctrine materially increases his chance to get the case before the jury. Although its application to collision cases is considerably limited by the requirement that the plaintiff's negligence must have ceased to operate at the time of the accident, counsel have made effective use of it in the crossing cases and in behalf of the jaywalking pedestrian. ${ }^{48}$

\section{Comparative Negligence}

The judicial exceptions to the doctrine of contributory negligence have been criticized because they allow an admittedly negligent plaintiff, whose fault contributed to his injury, to shift the entire burden of his loss to the defendant.99 To those who believe that liability based on fault is fundamentally unsound as applied to automobile cases, this criticism presents no difficulties. But if fault is to be the

4 Atchison, T. and S. F. Ry. v. Baker, 79 Kans. 183,98 Pac. 804 (1908), is a leading case.

"See Gibbard v. Cursan, 225 Mich. 311, 320, 196 N. W. 398, 401 (1923).

w See Lowndes, supra note 42, at 702 et seq., for discussion of the various reasons advanced for the exception.

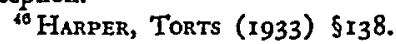

${ }^{47}$ The cases are discussed in Note (1934) 92 A. L. R. 47, 128. This is sometimes called the "humanitarian rule."

${ }^{49}$ Id. at 47 et seq.

"See Gregory, Legistative Loss Distribution in Negligence Actions (1936) 52. 
loss-shifting criterion in determining liability in these cases, it would seem that a system should be evolved which would alleviate the harshness of both the contributory negligence rule as applied to the plaintiff and the judicial exceptions thereto as applied to the defendant. It is in this direction that the liability reform pendulum now seems to be swinging.

Where one party asks that another compensate him for an injury caused by their joint negligence, the most equitable solution of the problem would be to allow him to recover only that proportion of the loss for which the other had been responsible. The courts, however, have consistently refused to apportion loss in negligence actions at common law. ${ }^{50}$ The reason usually advanced for this position are that the law will not settle disputes between wrongdoers ${ }^{51}$ and that it has no scales with which to measure the relative fault of negligent parties.52 The first has been attacked by almost every author who has had occasion to discuss contributory negligence. ${ }^{53}$ Especially is it subject to criticism as applied to automobile cases, wherein the plaintiff's "wrongs" are usually inadvertent and are scarcely ever intentional. Although the second has more merit, the courts without noticeable difficulty have apportioned negligence in other fields of the law..$^{54}$

The legislatures in several states, recognizing the harshness of the contributory negligence rule in the crossing cases, have provided that the plaintiff's recovery shall be diminished by the amount his fault contributed to his injury.5 In four states, the courts are authorized by statute to apportion the loss between plaintiff and defendant according to fault in all negligence actions. ${ }^{56}$ It is significant that the two most effective statutes, those of $\mathrm{Wisconsin}^{57}$ and Mississippi, ${ }^{58}$ have been passed since the advent of the automobile.

It is doubtless true that in accident cases, the judgment of a jury as to the proportion of the loss for which each party was responsible is at best extremely uncertain and inaccurate. But if the shifting of loss is to be based on fault, the comparative negligence statutes at least provide a more rational approach to the problem than the crude doctrines of the common law.

\section{Contribution between Joint Tortfeasors}

The same considerations which led the courts to refuse to apply the rule of comparative negligence have caused a great majority of them to hold that where one of two parties, whose joint negligence has caused injury to a third, has been compelled to pay the entire loss, he cannot obtain contribution from his co-tortfeasor. ${ }^{59}$

${ }^{5} \mathrm{Id}$, at 53 .

${ }^{5}$ HARPER, ToRTs. $\$ 132$. See in general as to the reasons behind the contributory negligence doctrine, BOHLEN, STUdies in TORTS (Ig26) 500.

${ }^{6}$ GREGory, op. cit. supra notc 49 , at 53 .

E.g., Mole and Wilson, $A$ Study of Comparative Negligence (1932) I7 Corn. L. Q. 332, 604.

Id. at 339-359.

The states are Georgia, Tennessee, Mississippi, and Wisconsin. Statutes are collected and discussed in Mole and Wilson, stupra, note 53, at 633 et seq.

${ }^{67}$ Wis. Laws I93 I, c. 242.

${ }^{58}$ Miss. Ann. Code (Hemingway, 1930) $\$ 5 \mathrm{II}$.

${ }^{*}$ Bohlen, Contribution and Indemnity Between Tortfeasors (1936) 21 CoRN. L. Q. 552. 
The leading case in support of this rule was one wherein the party asking for contribution had been a conscious wrongdoer. ${ }^{60}$ The courts of four states have distinguished this case from those wherein the parties were merely negligent, and allow contribution in the latter. ${ }^{01}$ Statutes have been enacted in about one-fourth of the states, allowing contribution in tort actions where the plaintiff was not an intentional wrongdoer. ${ }^{62}$ These decisions and statutes were undoubtedly intended to allow contribution in automobile accident cases as well as in other negligence actions. However, one court has held that the breach of a highway safety statute is such conscious wrongdoing as will exclude the actor from contribution. ${ }^{63}$ Since highway codes regulate practically every move the automobile driver is likely to make, such holdings would be fatal to contribution in accident cases. ${ }^{64}$ It has been suggested that future statutes should be carefully worded so as to exclude the possibility of this interpretation. ${ }^{65}$

That the growing interest in comparative negligence and contribution legislation is due mainly to automobile accident litigation, there can be no doubt. Although such legislation is intended not to destroy but to refine the fault formula for shifting loss, it is indicative of the general dislike for those harsh rules of the common law which would deny recovery to all but that rare individual who was entirely free from fault.

\section{The OWNer's Responsibility for the Driver's Negligence}

In the days when an automobile driver was looked upon with somewhat that same degree of awe and respect which the airplane pilot inspires in the ordinary ground dweller of today, the owner did not often entrust his car to others. He either drove it himself or, since he was usually a man of wealth, employed an experienced chauffeur. There were few cases, therefore, in which the owner's liability for injuries caused by the negligent operation of his automobile could not be predicated either on his own fault or on that of his regularly employed servant. Once the novelty of the new machines began to wear off and the members of the owner's family discovered that operating the family automobile was not much more difficult and a great deal more thrilling than driving the family horse, cases arose in which the owner's liability coúld not so readily be fitted into traditional legal formulas. With the coming of the present era when the loaning of automobiles both gratuitously and for hire is an ordinary occurrence, plaintiffs in an increasing number of cases have asked the courts to hold a solvent automobile owner liable for the negligence of a financially irresponsible driver.

${ }^{\infty}$ Merryweather v. Nixan, 8 T. R. 186, Ior Eng. Repr. 1337 (K: B. 1799).

ou Bohlen, loc. cit. supra note 59.

The statutes are collected in Leflar, Contribution and Indemnity Between Tortfeasors (1932) 81 U. OF PA. L. REv. I30 n. 60 .

Fidelity and Casualty Co. of N. Y. v. Christenson, I83 Minn. 182, 236 N. W. 618 (193I).

* Leflar, supra note 62, at 144 .

${ }^{\infty}$ Id. at I45; GreGoRY, op. cit. supra note 49 , at I4I. 
In no other branch of automobile law have the courts shown more willingness to stretch the legal formulas at their command in order to reach desired results than in dealing with this problem. By refusing to classify the automobile as a dangerous instrumentality, ${ }^{66}$ they deprived themselves of the most effective legal tool by which liability on the owner could have been imposed. Forced to use more conventional formulas, they have, nevertheless, in a surprisingly large number of cases, succeeded in finding some ground on which to hold the owner liable.

\section{x. The Owner's Liability for Choosing an Incompetent Driver}

Although the courts refuse to classify the automobile as a dangerous instrumentality, they recognize that it may become dangerous unless carefully driven. ${ }^{67}$ Therefore the owner may subject himself to liability if he knowingly entrusts his car to a driver who is incompetent for want of age or experience, ${ }^{68}$ or who has a reputation for recklessness. ${ }^{69}$ The scope of this liability is greatly limited due to the difficulty of proving the owner's knowledge of the driver's inefficiency. The courts have made use of several devices in an attempt to aid the plaintiff in this respect. Thus it has been held that it is enough if the owner had every reason to believe that the driver was incompetent. ${ }^{70}$ A father who knows that his son is addicted to drinking cannot escape liability for accidents caused by the son's drunken driving. ${ }^{71}$ Where the driver is below the legal age the courts are likely to leave the question of knowledge to the jury. ${ }^{72}$ One who rents automobiles must make reasonable efforts to determine whether or not the prospective renter is a competent operator. ${ }^{73}$ Although the courts insist that the owner is held liable in this situation only for his own negligence, a study of the opinions will disclose that the liability imposed is in fact based on the driver's negligence, and that finding the owner negligent is in most cases merely a convenient method of insuring compensation to the plaintiff.

\section{The Owner's Liability under the Master-Servant Formula}

The rule that a master should be liable for the torts of his servants was first laid down almost two hundred years before the invention of the automobile. ${ }^{74}$ But the limits to which it might be extended were not realized until the courts began to look for convenient pegs on which to fasten the liability of the automobile owner for a driver's negligence. For even in those jurisdictions which do not recognize that most startling extension of the rule, the family purpose doctrine, the courts have been liberal in fitting individual cases into the traditional master-servant formula.

\footnotetext{
os Florida, until r93r, did impose liability on the owner on this ground. Southern Cotton Oil Co. v. Anderson, 80 Fla. 44I, 86 So. 629 (1920). For the present Florida rule, see Brown, $A$ Comment on the Duties and Responsibilities of a Motor Vehicle Owner in Florida (1932) 5 Fra. State BAR Assn. L. J. 469.

${ }^{\circ}$ Allen v. Bland, I68 S. W. 35 (Tex. Civ. App. I914).

Ibid.

\%ones v. Harris, 122 Wash. 69, 210 Pac. 22 (1922).

${ }^{70}$ Robertson v. Aldridge, I 85 N. C. 292 , I16 S. E. 742 (1923).

${ }^{71}$ Crowell v. Duncan, 145 Va. 459,134 S. E. 576 (r926).

${ }^{72}$ Cases collected in Note (1925) 36 A. L. R. II37, II50.

"Anderson v. Driverless Cars, Ir La. App. 515, 124 So. 312 (1929).

"Jones v. Hart (1698) Holt, K. B. 642, 90 Eng. Repr. 1225.
} 
Thus it is held that the owner's presence in the automobile will create a strong inference that a master and servant relationship existed between him and the driver. ${ }^{75}$ Where the driver is a member of his family the inference is almost conclusive. ${ }^{76}$ Although the courts generally talk in terms of power and right to control in justifying the imposition of liability, ${ }^{77}$ its real basis is probably more nearly expressed by this language of the Supreme Court of Maine used in reference to the automobile owner: "You shall not be permitted to shuffle yourself down to the bottom of the pack as a mere passenger and turn up a probably impecunious and irresponsible driver as the only person subject to legal liability. ${ }^{78}$

The requirement that the servant must have been acting within the scope of his employment provides a convenient loophole through which the master can escape liability, but some courts have gone far in holding him liable in such cases. ${ }^{70}$ Needless to say, the jury coopperates in this endeavor. The difficulty of proving that the driver and owner were servant and master, and that the servant was acting in the scope of his employment, has been greatly alleviated in a majority of jurisdictions by the fact that the courts hold that proof of ownership is prima facie evidence of the owner's responsibility for the driver's negligence. ${ }^{80}$ Unless this presumption is met by the evidence of disinterested witnesses, the case will go to the jury. ${ }^{81}$

\section{The Owner's Liability under the Family Purpose Doctrine}

So radical an extension of the traditional agency formula is the family purpose doctrine that it has been described as a new form of tort liability evolved by the courts in order to increase the owner's responsibility for the automobile driver's negligence. That the courts, to a degree, have recognized this fact is illustrated by the language used in the leading case of King v. Smythe, "We think the practical administration of justice between the parties is more the duty of the court than the preservation of some esoteric theory concerning the law of principal and agent." 83

The term, family purpose doctrine, is a misleading one. For in those jurisdictions where liability will be imposed only under strict agency rules, a master-servant relationship may be found, if the driver was using the car for a family purpose, in

${ }^{75}$ Smith v. Wells, 326 Mo. $525,3 \pi$ S. W. (2d) sor 4 (1930).

${ }^{76}$ Haigh v. Hill, 65 Cal. App. 517, 224 Pac. 474 (1924).

$\pi$ "E.g., Fulles v. Metcalf, 125 Me. 77, 130 Atl. 875 (.925).

${ }^{78}$ Id. at $8 \mathrm{r}, 130 \mathrm{Atl}$. at 879 .

${ }^{73}$ Where a servant, without authority, allows another to drive the automobile, the negligence of the other may be imputed to the master if the servant was in the car when the accident occurred. Cf. Grant v. Knepper, 245 N. Y. 158,156 N. E. 650 (1927). Although it is well established that the master will not be liable where the servant is on a frolic of his own, the courts have realized to a degree that the servant entrusted with an automobile is placed in such a position that at least some deviations from the line of duty should be expected by the master. Thus the deviation may be classed only as a detour if the servant was pursuing a general course necessary to accomplish the master's business. Hcaly v. Cockrill, 133 Ark. 327, 202 S. W. 229 (1918); see, further, Smith, Frolic and Detour (1923) 23 Cou. L. REv. $444,716$.

${ }^{80}$ For an excellent article showing the effect of the automobile on the adoption of this rule in the state, see Fegan, Presumption versus Proof in Automobile Highway Accidents (1934) 22 Gro. L. J. 750.

an Miller v. Service and Sales, Inc., 149 Ore. II, 38 P. (2d) 995 (1934).

${ }^{52} 140$ Tenn. 217,204 S. W. 296 (1918).

${ }_{3}^{3}$ Id. at 226,204 S. W. at 298. 
the strict sense of the term. Thus where other members of the family were riding in the car, the courts have found that the driver was acting as a chauffeur. ${ }^{84}$ And if the driver, though riding alone, was running a family errand, such as making a purchase of food, the owner will be held liable under strict agency rules. ${ }^{85}$ It is only when the driver is using the car not for a purpose beneficial to the family, but for his own pleasure, that the case will not fit into the traditional agency formula. It is in defining the family purpose that the courts disagree. Those who would hold the owner liable where the driver was using the car solely for his own pleasure, declare that the business of providing pleasure and recreation for members of the family is as much a family purpose as that of providing food and clothing. ${ }^{86}$ The fallacies in this line of reasoning have been pointed out by the New York Court of Appeals: "We have never heard it argued that a man who kept for family use a horse and wagon, a boat, or set of golf sticks had so embarked upon the occupation of furnishing pleasure to members of his family that if sometime he permitted one of them to use one of those articles for his personal enjoyment, the latter was engaged in carrying out not his own purpose but as agent the business of his father." ${ }^{\prime 87}$

However weak it may be when measured in terms of established legal formulas, the doctrine has proved an effective weapon, in those courts which recognize it, for imposing liability upon the owner of the family automobile. These courts have been as liberal in interpreting the rules for its application as they were in defining the family purpose. Thus, a husband who gave a car to his wife was held liable under the doctrine although he had no property interest therein. ${ }^{88}$ Although, the husband is the head of the family, at least in the eyes of the law, a wife has been held liable for her husband's negligence in driving her car. ${ }^{89}$ A car purchased for business purposes, may come within the rule if it is at times used for the family's pleasure..$^{90}$ The owner's family, broadly defined in one case as including all the members of a collective body of persons living in one household and under one roof, ${ }^{91}$ has been held to include a partially self-supporting adult son living with his parents, ${ }^{92}$ a housekeeper, employed for a number of years by a priest, ${ }^{93}$ and parents living with their children.94 It may be found that the owner impliedly consented to the use where he expressly prohibits a child from driving, if his passive acquiescence thereto is subsequently given; ${ }^{95}$ where the permission is restricted and the driver exceeds it, the court may leave to the jury the question of substantial com-

\footnotetext{
Missell v. Hayes, 86 N. J. L. 348, 9 I Atl. 322 (I9I4).

${ }^{80} \mathrm{McC}$ affrey v. Lukens, $67 \mathrm{~Pa}$. Super. 231 (19r7).

${ }^{86}$ Jones v. Cook, 90 W. Va. 7ro, III S. E. 828 (I922).

${ }^{87}$ See Van Blaricom v. Dodgson, 220 N. Y. IxI, II5, II5 N. E. 443, 445 (I917).

${ }^{63}$ Cohen v. Hill, 286 S. W. 66, (Tex. Civ. App. 1926).

${ }^{\circ}$ Venghis v. Nathanson, ror N. J. L. I10, 127 Atl. 175 (1925).

Watson v. Burley, Io5 W. Va. 516, I43 S. E. 95 (I928).

${ }^{01}$ Ṡmart v. Bissonette, 106 Conn. 447, 138 Atl. 365 (1927).

Watson v. Burley, supra note go. Smart v. Bissonette, supra note gr.

« Turner v. Gackle, I68 Minn. 5I4, 209 N. W. 626 (I926).

ws Wallace v. Squires, 186 N. C. 338 , I 19 S. E. 569 (I923).
} 
pliance. $^{\theta 8}$ And liability may be imposed on the owner where the accident occurred while the car was being used for an expressly forbidden purpose. ${ }^{.7}$

These cases, though they illustrate the extremes to which the doctrine has been carried, indicate that the courts which recognize it are concerned more with the desirability of insuring recovery to injured plaintiffs than they are with maintaining the symmetry and balance of traditional liability patterns.

\section{Statutory Extensions of the Owner's Liability.}

A number of those who have criticized the attempted legal rationale of the family purpose doctrine have, nevertheless, commended the courts which follow it for their refusal to allow traditional legal formulas to stand in the way of needed reforms. ${ }^{98}$ If the subsequent history of the owner's liability for the driver's negligence is any criterion, the wisdom of such judicial legislation is open to serious doubt. In recent years statutes have been enacted extending the owner's liability to all cases where the car was driven with his consent. 99 Of the six states ${ }^{100}$ in which legislation of this character has been adopted, in only one, ${ }^{101}$ had the courts, prior thereto, recognized the family purpose doctrine. This would seem to indicate that the need for such legislation, imposing an exceedingly broad liability, has been more keenly felt in those states where the courts refused to extend the liability of the owner beyond the recognized common law limits, than in those where they attempted a partial solution of the problem by holding the owner liable in a substantial but limited group of cases through the application of the family purpose doctrine. However, the courts have construed these statutes so strictly that there is still a fairly large group of cases which do not fall within their scope.

It is generally held that they are not applicable where the relationship of master and servant exists between the owner and driver. ${ }^{102}$ Thus the master's freedom from liability where the servant acts outside the scope of his authority is not affected. The term owner is generally held not to include a conditional vendor or chattel mortgagee. ${ }^{103}$ The consent requirement is much more strictly construed than under the family purpose doctrine. Wherc the driver keeps the car beyond a named hour ${ }^{104}$ or where he drives to a different place from the one authorized, ${ }^{105}$ the owner

${ }^{\infty}$ Johnson v. Evans, 141 Minn. 356, r 70 N. W. 220 (1919).

" McDowell v. Hurner, 142 Ore. 6r7, 20 P. (2d) 395 (19.33).

${ }^{83}$ E.g., see McCall, The Family Attomobile (193n) 8 N. C. L. Rev. 256, 270.

${ }^{\infty}$ For collection of statutes and discussion of their scope, sec Hcyting, Automobiles and Vicarions Liability (1930) 16 A. B. A. J. 225; Reno, Imputed Negligence in Attomobile Bailments (1934) 82 U. op PA. L. Rev. 213, 219-225.

${ }^{100}$ California, Iowa, Michigan, New York, and Rhode Island have thi; type of statute. Massachusetts with its compulsory insurance act, obtains the same result. See Reno, supra note 99, at 224 .

${ }^{301}$ Iowa. Sec McCall, supra note 98, at 256.

12 Psota v. Long Island R. Co., 246 N. Y. 388 , 159 N. E. I 80 (1927).

${ }^{100}$ Lennon v. L. A. W. Acceptance Corp., 48 R. 1. 363 , 138 Atl. $25_{5}$ (1127).

${ }^{20}$ Union Trust Co. v. American Commercial Car Co., 219 Mich. 557, 189 N. W. 23 (1922).

${ }^{20 s}$ Chaika v. Vanderberg, 252 N. Y. 101, 169 N. E. 103 (1929). 
may be relieved from liability, and where the car is loaned for a specific purpose the owner is not liable if it is used for another. ${ }^{106}$

The necessity for judicial and legislative extensions of the owner's liability is today rapidly diminishing. Only when the owner is financially responsible, will the plaintiff desire to pursue his remedies against him rather than the driver. It can be said, without fear of contradiction, that the great majority of financially responsible automobile owners today carry casualty insurance. Most of these policies now contain an "omnibus" clause, which extends the coverage to all who drive the car with the owner's consent. ${ }^{107}$ Very possibly the inclusion of this clause has to a considerable degree been induced by the increased responsibility which courts and legislatures have imposed upon the automobile owner.

\section{The Automobile Guest}

Having witnessed in the preceding sections the gradual undermining of those portions of the common law fault formula which bar the paths of plaintiffs to recovery, it is somewhat surprising to discover that a rising tide of decisions and statutes is now threatening to engulf completely the common law rights and remedies of a special class of accident victims, automobile guests. A survey of the history of host-guest litigation may reveal some of the factors which have caused the courts and legislatures to make this discrimination.

The driver of the horse and buggy owed to his guest the common law duty of ordinary care. ${ }^{108}$ Except in the courts of Massachusetts, ${ }^{109}$ the same standard was applied in the early cases to the conduct of the automobile host. Through some of the opinions, however, there runs an undercurrent of judicial aversion to host-guest litigation. It was felt that the act of an owner of a car in loaning its "comfort and pleasure to his less fortunate neighbor ... was a species of hospitality which should be encouraged ... and that the law should not couple with the friendly at a dusy which makes its exercise an unreasonable hazard."110 Beginning approximutely in 1920, the volume of host-guest litigation greatly increased.11 Closc litionds and relatives seemed to forget the sacial niceties and without reluctance bcime opponents in the court room. The courts, however, looking beyond the litigunts at bar, discovered that there had also been a great increase in casualty'insur.mce. "': Realizing

${ }^{200}$ Heavilin v. Wendell, 214 Iowa $844,24 \mathrm{I}$ N. W. 654 (1932). In adlitusn wh the stites which have comprehensive statutes of this type, others have enacted legislation which deals only with some of the most pressing aspects of the general problem. For discussion of statutury lisbility for the accidents of minors, see Legis. (r935) 48 Harv. L. Rev. 498. Connecticut, Maine, and New Jersey are among the states which impose vicarious liability on those who rent cars. Seç Reno, loc. cit. suprat note 99.

${ }^{107}$ For the effect of this clause, and the consent required thereunder. sce Note (1935) 82 U. of: PA. L. Rev. 765 . Several states require by statute that this clause be included in all policics. Sec Lcgis. (1933) 8 WIS. I. Rev. 349.

${ }_{103}$ Several of the cases are discussed in Avery v. Thompson, I17 Me. 120, 103 Atl. 4 (1918).

${ }^{200}$ Massaletti v. Fitzroy, 228 Mass. 487 , I88 N. E. I68 (I9I7), (requiring the guest to prove gross negligence by host).

${ }^{110}$ O'Shea v. Lavoy, 175 Wis. $456,459,185$ N. W. 525,527 (1921).

${ }^{211}$ Sec White, The Liability of an Automobile Driver to a Non-Paying Passenger (1934) 20 VA. L. REv. 326, 332. 
the high possibility of collusion in such cases, they began to place restrictions upon the guest's right to recover. What would constitute contributory negligence or assumption of risk on his part was no longer left entirely to the judgment of the jury, but was spelled out into exact rules by the appellate courts in order that the trial judge might more often decide the fault issue. ${ }^{118}$ In three states the Massachusetts common law rule requiring the guest to prove his host grossly negligent, was adopted by the courts. ${ }^{114}$ In 1927 , the legislatures, influenced perhaps by both the vexatious character of host-guest litigation and the insurance lobbies, began to place stringent limitations upon the common law rule. During the past nine years seventeen states have adopted statutes which allow recovery to a guest only if his host has been guilty of conduct more blameworthy both in degree and in quality than ordinary negligence. ${ }^{115}$ Most of these statutes require the guest to prove that his host had shown a reckless disregard for the rights of others. ${ }^{118}$ Some provide that the host's conduct must have been willful or intentional, ${ }^{117}$ others that it must have been grossly negligent. ${ }^{118}$ Only the rights of the non-paying guest are thus limited.110

It has been said that the obvious purpose of this legislation is to deny recovery to the social guest unless his host has been so neglectful of his safety that the guest owes him no gratitude.120 However, there is little doubt but that the legislatures have been influenced more by the possibilities of collusion between an insured host and his guest than by their dislike for the ungracious guest. ${ }^{121}$

The history of liability in automobile accident litigation discloses a definite trend away from the strict fault concepts of the common law. The courts, though speaking always in terms of fault, have at times stretched the traditional formulas to the breaking point in order to insure recovery to an injured plaintiff. In this respect they have found an always willing ally in the jury. Nor have the legislatures proved reluctant to aid them. Yet the decisions and statutes restricting the rights of the automobile guest indicate that, where reinforced by the average man's dislike of the ingrate or of collusion in fraud, the concept of fault has gained, rather than lost, in vitality.

118 See cases collected in Mechem, The Contributory Negligence of Automobile Passengers (1930) 78 U. OF PA. L. REv. 736, 740.

${ }^{116}$ They are Georgia (Epps v. Parrish, 26 Ga. App. 399, 106 S. E. 297 (1921)); Washington (Saxe v. Terry, 140 Wash. 504, 250 Pac. 27 (1920)) and Virginia (Boggs v. Plybon, 157 Va. 30, 160 S. E. 77 (1930)).

IIs The statutes are collected in White, supra note $\mathrm{IrI}$, at 326-327.

${ }^{110}$ E.g., Conn. Gen. Stat. (1930) \$1628.

${ }^{117}$ E.g., Calif. Laws I931, p. 1693. $\quad{ }^{118}$ E.g., Ore. Sess. Laws 1929, $\$ 550$.

${ }^{210}$ As to who is a guest within these statutes, see Notes (1933) 82 A. L. R. 1365; (1935) 95 A. L. R. 1780 .

100 See Note (1933) I8 CorN. L. Q. 621, 622.

$20 x$ See language of court justifying such legislation in Naudzius v. Lahr, 253 Mich. 216, 224, 234 N. W. 58I, 584 (193I). 